\title{
Virus-like particles in the tracheal mite Acarapis woodi (Rennie)
}

\author{
TP Liu *** \\ University of California, Department of Entomology, Davis, CA 95616, USA
}

(Received 8 August 1990; accepted 10 March 1991)

\begin{abstract}
Summary - Tracheal mite infected honey bees were collected from Scotland and from California. The lyzed cells of the body cavity of tracheal mites in the honey bees collected from Scotland harboured numerous $27 \mathrm{~nm}$ isometric virus-like particles. These virus-like particles were formed in a crystalline array and were arranged in a hexagonal pattern. No virus-like particles were observed in the tracheal mites of the honey bees collected from California. The significance of these observations in relation to the honey bee tracheal mite resistance is discussed.
\end{abstract}

honey bee / Acarapis woodi / virus-like particle / electron microscopy

\section{INTRODUCTION}

The continuing range expansion of tracheal mite Acarapis woodi (Rennie) (Acari, Tarsonemidae) infestation in Canada and the United States has prompted experiments in order to find chemical means of controlling this damaging honey bee disease (Guzman-Novoa and ZozayaRubio, 1984; Anonymous, 1986; Gruszka, 1987; Wilson et al, 1988; Eischen et al, 1989). Chemical control of the tracheal mite is very attractive because of its relatively low cost application and reliability. Unfortunately, consumers are increasingly aware of environmental pollution and food safety issues associated with nearly $50 \mathrm{yr}$ of synthetic and organic pesticide use. Chemical residue problems will certainly affect the marketability of honey which is harvested from bee hives treated with pesticides. An attempt has also been made to import British honey bees in order to introduce natural tracheal mite resistance to the North American stocks (Morse, 1990). Breeding tracheal mite resistant honey bees is certainly the most desirable approach to reduce the damage caused by tracheal mite infestation. Biological control of tracheal mite infestation,

\footnotetext{
* This work was performed during sabbatical leave.

** Present address and affiliated institution: Box 29, Agriculture Canada Research Station, Beaverlodge, Alberta,Canada TOH OCO
} 
may be one of the other attractive alternatives. Because biological control is based on organism interaction, it involves ecological studies of factors that regulate or affect interaction. Attempts have been made during the last $5 \mathrm{yr}$ to find organisms which have the potential of becoming biological control agents in tracheal mites, or are associated with tracheal mites. This paper describes the ultrastructural features of virus-like particles found in the lyzed tissue of some tracheal mites.

\section{MATERIALS AND METHODS}

Tracheal mite infected honey bees were collected from Buckham, Scotland during the summer of 1985 . Infected honey bees were fixed in $8 \%$ EM grade glutaraldehyde (Polyscience, Warrington, PA) before being shipped to Canada. Specimens were also collected during 19881989 from Vacaville, CA. Tracheae with heavy mite infestation were dissected in saline and transferred to vials containing $4 \%$ glutaraldehyde in 0.2 M phosphate buffer, $\mathrm{pH} 7.4$ (Liu et al, 1989). Specimens were fixed overnight at $4^{\circ} \mathrm{C}$, rinsed in the buffer, postfixed in $1 \%$ osmium tetroxide in the same buffer, dehydrated in a graded ethanol series, and embedded in Polybed 812 (Polyscience, Warrington, PA). Silvergray sections were cut on a Sorval MT2 ultramicrotome with glass knives, and mounted on 400-mesh copper grids. Sections were stained with uranyl acetate followed by lead citrate then examined and photographed with a Philips EM 410 or 400 electron microscope operated at an accelerating voltage of $80 \mathrm{Kv}$.

\section{RESULTS}

Of 51 tracheal mites from 17 Scotland honey bees examined, 3 mites from 2 individual bees harboured virus-like particles. Of 75 tracheal mites from 27 California honey bees examined, no virus-like particles were found. In all of the tracheal mites from which virus-like particles were detect- ed, tissues were extensively lyzed, and these mites appeared to be dead before fixation. Residual membranes and large lamellar bodies were also observed (figs 13). All of the virus-like particles were packed in crystalline arrays in a hexagonal arrangement (figs 1, 3-4), while scattered single particles were rarely observed. These particles, exclusively found within the mites, were isometric and measured $27 \mathrm{nM}$ in diameter, and were not embedded in protein matrices. None of them had been observed in the tracheal lumen. In 2 of the mites, the entire body cavity appeared to be filled with these virus-like crystalline inclusions (fig 2). At higher magnification the particles consisted of a dense core ringed by an electron-dense coat (fig 4).

\section{DISCUSSION}

These virus-like particles found in the tracheal mites bear a close resemblance to some of the honey bee viruses (Bailey, 1976, 1981; Bailey et al, 1980, 1981). The identification of the small isometric viruslike particles is handicapped by the lack of fresh tracheal mites infected by this virus. Ultrastructural appearance of these particles described in the present study resembles several insect picornaviruses, including the $\mathrm{P}$ virus of Drosophila melanogaster (Teninges and Plus, 1972), and the grasshopper crystalline array virus (Henry and Oma, 1973). These small viruses typically form cytoplasmic crystalline arrays. This type of virus has been described in many invertebrates (Longworth, 1978). Picornaviruses are single-stranded RNA viruses, ranging in size from 22-30 $\mathrm{nm}$ (Matthews, 1982). Many small honey bee RNA viruses in Britain, such as black queen cell, acute paralysis and Kashmir viruses, have a dimension of $30 \mathrm{~nm}$. Viruses $Y$ and $X$ are 


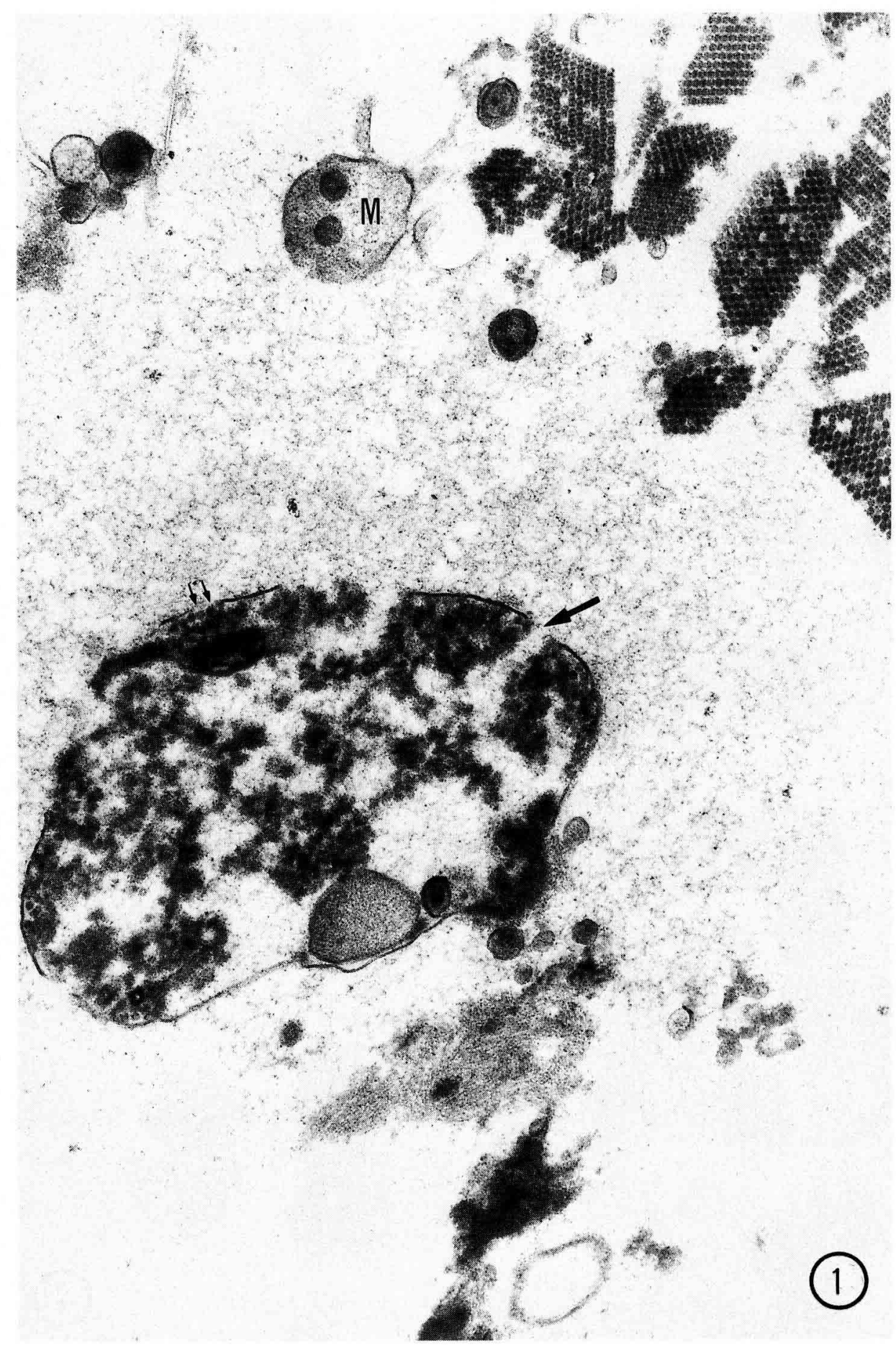

Fig 1. A lyzed cell in the body cavity of a tracheal mite. Virus-like particles are visible (small arrows) among residual membranes. In the cytoplasm there are residual membranes (M) and virus-like particles in the form of paracrystals ( $x 39000$ ). 


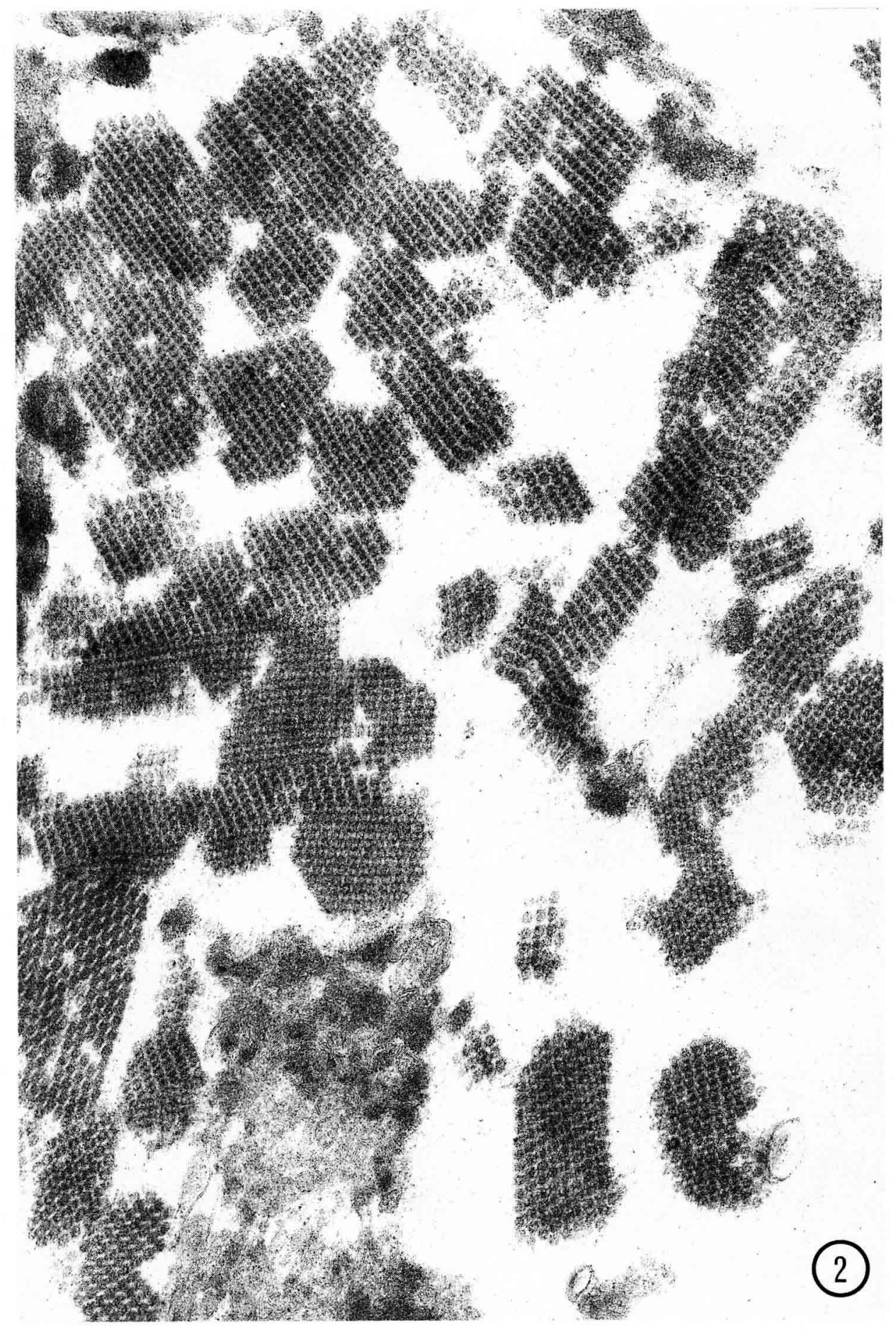

Fig 2. Most of the lyzed cells of a tracheal mite are filled with tightly packed virus-like particles in the form of paracrystals $(x 45000)$. 
$35 \mathrm{~nm}$ in size. The very common cloudy wing particle virus is $17 \mathrm{~nm}$ in size (Bailey, 1981). The size of these honey bee virus particles is either larger of smaller than the virus particles observed in the tracheal mites. Due to a lack of thin-section electron microscope studies, it is impossible to make a direct comparison between the honey bee viruses and the virus-like particles in the tracheal mites, concerning the size of the virus particles and the pattern of cytoplasmic crystalline arrays. In addition, the large number of virus crystals found in the tracheal mites is always associated with cellular debris, which is an indication that these particles replicated themselves within the cells of tracheal mites. Therefore, it is unlikely that these particles are honey bee viruses ingested by the tracheal mites.

Viruses of any kind have not previously been described in the tracheal mite. Because these virus-like particle were found in the extensively lyzed cells, it could indicate that they are lethal to the tracheal mites.These particles were found among cellular debris of the lyzed cells, which is an indication of the multiplication that took place in the cells and accumulated in the cytoplasm. All of these virus-like particles were found in the mites from honey bees collected in Scotland. None have been observed in the mites from the honey bees collected in California. Because of the sample size the extent of the infection in the tracheal mite population within the

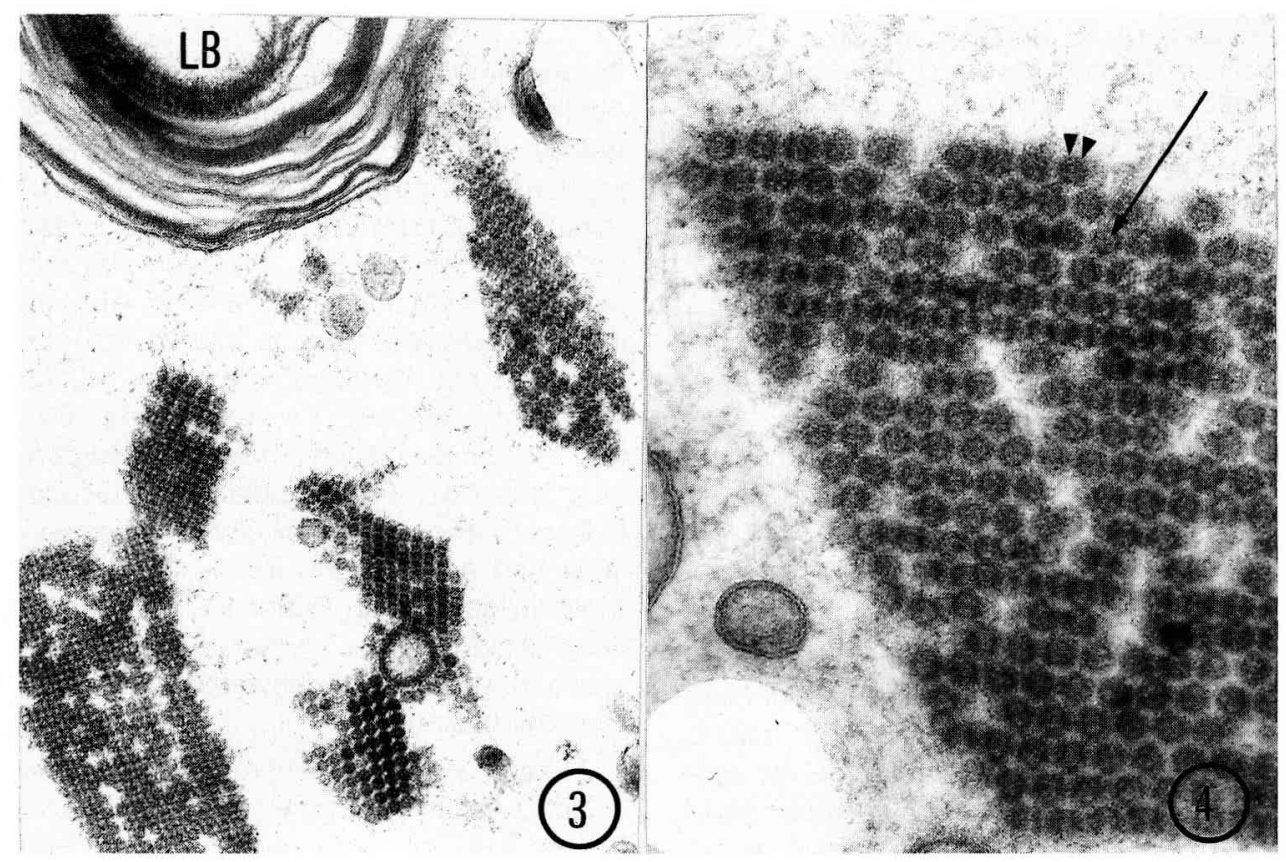

Fig 3. Most of the lyzed cells contain a large number of lamellar bodies (LB) and virus-like particles (x 39000$)$.

Fig 4. Higher magnification view of the virus-like particles which have an electron-dense core (arrow) and an electron-dense coat (arrowheads). Note that these particles are arranged in a hexagonal pattern ( $x 105000)$. 
cotland honey bees it not certain. Since these virus-like particles have not been observed in the tracheal mites from the California honey bees, it is quite possible that the British honey bees are more resistant to tracheal mite infestation due to the presence of a viral desease in the tracheal mite population. The tracheal mite population in the British honey bees may be subjected to viral disease regulation. An extensive survey is underway to determine the incidence and pathogenicity of these virus-like particles, in order to demonstrate the above postulation.

\section{ACKNOWLEDGMENTS}

The author wishes to thank members of the Bee Biology Facilities, University of California, Davis Campus, for their hospitality and to M Mobus, North Scotland Agricultural College, for collecting specimens in Scotland. This work was supported by the work transfer program, Agriculture Canada.

\section{Résumé - Des particules de type viral chez l'acarien Acarapis woodi (Rennie).} Des abeilles (Apis mellifera $\mathrm{L}$ ) parasitées par l'acarien des trachées, Acarapis woodi (Rennie) (Acari, Tarsonemidae), ont été prélevées à Aberdeen (Écosse) en 1985 et à Vacaville (Californie) en 1988-1989. Les trachées des abeilles fortement parasitées ont été disséquées dans du liquide physiologique et transférées dans des récipients contenant $4 \%$ de glutaraldéhyde dans un tampon phosphate à 0,2 mol..$^{-1}$, $\mathrm{pH} 7,4$. Les trachées renfermant des acariens ont été laissées dans ce milieu toute une nuit à $4^{\circ} \mathrm{C}$ puis rincées dans le même tampon et fixées au tétroxyde d'osmium à $1 \%$ dans le même tampon durant $1 \mathrm{~h}$. Elles ont été ensuite déshydratées progressivement par l'alcool éthylique et montées dans du Polybed. Des coupes minces ont été réalisées au microtome, colorées à l'acétate d'uranyle et au citrate de plomb, puis examinées en microscopie électronique (Philips EL 400) à $80 \mathrm{kV}$. Les Acarapis des abeilles venant d'Écosse renfermaient dans les cellules lysées des particules de type viral. Ces particules isométriques de $27 \mathrm{~nm}$ se présentaient sous forme cristallisée dans une disposition hexagonale. II n'y avait pas de particules de type viral chez les Acarapis des abeilles provenant de $\mathrm{Ca}$ lifornie. II est possible que ces abeilles soient plus résistantes à $A$ woodi à cause de la présence d'une virose chez ce dernier.

\section{Acarapis woodi / particule de type viral / microscopie électronique}

\section{Zusammenfassug - Virus-ähnliche} Partikel bei der Tracheenmilbe Acarapis woodi. Von Tracheenmilbe befallene Honigbienen wurden 1985 in Aberdeen, Schottland, und 1988/1989 in Vaccaville, Kalifornien, gesammelt. Tracheen von mit Milben schwer befallenen Bienen wurden in Insekten-Salzlösung präpariert und in Gläschen mit $4 \%$ Glutaradehyd in $0.2 \mathrm{M}$ Phosphatpuffer, $\mathrm{pH} 7.4$, übertragen. Die mit Milben besetzten Tracheen wurden über Nacht bei $4^{\circ} \mathrm{C}$ in dieser Fixierlösung belassen, dann mit demselben Puffer gespült und anschießend in $1 \%$ Osmiumtetroxid in demselben Puffer für $1 \mathrm{~h}$ nachfixiert. Die Präparate wurden dann stufenweise in Äthylalkohol dehydriert und in Polybed eingebettet.

Mittels Glasmesser hergestellte Dünnschliffe wurden mit Uranylazetat und Bleizitrat gefärbt und unter einem Philips EM 400 Elektronenmikroskop bei einer Beschleunigungs-Spannung von $80 \mathrm{kv}$ untersucht. Einige der Tracheenmilben aus Bienen, die in Schottland gesammelt worden waren, enthielten Virus-ähnliche 
Partikel in aufgelösten Zellen (Fig. 1, 3, 4). Diese $27 \mathrm{nM}$ messende isometrischen Virus-ähnlichen Partikel befanden sich in kristalliner Anordnung mit hexagonalem Muster. In den Milben, die aus in Kalifornien gesammelten Bienen stammten, wurden keine Virus-ähnlichen Partikel gefunden. Es wird vermutet, daß ein Zusammenhang zwischen diesem Befund und der erhöhten Milbenanfälligkeit der Bienen in Kalifornien bestehen könnte.

\section{Honigbiene / Acarapis woodi / Virus- ähnliche Partikel / Elektronen- Mikroskopie}

\section{REFERENCES}

Anonymous (1986) Manitoba quarantines tracheal mite infested colonies. Am Bee $J 126$, 589

Bailey L (1976) Viruses attacking the honey bee. Adv Virus Res 20, 271-304

Bailey L (1981) Honey Bee Pathology. Academic Press, London

Bailey L, Ball BV, Carpenter JM, Woods RD (1980) Small virus-like particles in honey bees associated with chronic paralysis virus and with a previously undescribed disease. $J$ Gen Virol 46, 149-155

Bailey L, Ball BV, Perry JN (1981) The prevalence of viruses of honey bees in Britain. Ann Appl Biol 97, 109-118

Eischen FA, Cardoso-Tames D, Dieta A, Ware GO (1989) Cymiazole, a systemic acaricide that controls Acarapis woodi (Rennie) infest- ng honey bees. II. An apiary test. Apidologie 20, 41-51

Gruszka J (1987) Honey bee tracheal mites: are they harmful ? Am Bee J 127, 653

Guzman-Novoa E, Zozaya-Rubio A (1984) The effects of chemotherapy on the level of infestation and production of honey in colonies of honey bees with acariosis. Am Bee $J$ 124, 669-672

Henry JE, Oma EA (1973) Ultrastructure of the replication of the grasshopper crystalline array virus in Schistocera americana compared with other picornaviruses. J Invertebr Pathol 21, 273-281

Liu TP, Mobus B, Braybrook G (1989) Fine structure of hypopharyngeal glands from honeybees with and without infestation by the tracheal mite, Acarapis woodi (Rennie). $J$ Apic Res 28, 85-92

Longworth JF (1978) Small isometric viruses of invertebrates. Adv Virus Res 23, 103-157

Matthews REF (1982) Classification and nomenclature of viruses. Fourth report of the International Committee on Taxonomy of Viruses. Intervirology 17, 1-200

Morse RA (1990) Importation of British queen honey bees into the United States. Am Bee $J$ $130,106-120$

Teninges D, Plus N (1972) P virus of Drosophila melanogaster, as a new picornavirus. $J \mathrm{Gen}$ Virol 16, 103-109

Wilson WT, Moffett JO, Cox RL, Maki DL, Richardson H, Rivera R (1988) Menthol treatment for Acarapis woodi control in Apis mellifera and the resulting residues in honey. In: Africanized Honey Bees and Bee Mites (Needham GR, Page RE, Delfinado-Baker M, Bowman CE, eds) John Wiley and Sons, NY, 535-540 